\title{
Caring In-Between: Events of Engagement of Preschool Children and Forests
}

\author{
Anna Vladimirova
}

Anna Vladimirova is a $\mathrm{PhD}$ candidate in education at the University of Oulu, Finland. Her research interests include body-place relations, the problematics of care in multispecies encounters, and the role of embodied movement in environmental sustenance. Drawing on philosophies of new materialism and posthumanism, she currently explores the implications of children-nature relations for environmental education. Her work also aims to contribute to rethinking an increasingly anthropocentric notion of forest from an educational perspective. Email: anna.vladimirova@oulu.fi

This paper draws on process philosophy to imagine "care" as a collective practice of children and the forest in the context of Finnish early childhood education. By locating care in movement rather than an individual, the author challenges the notion of caring subjectivity and employs postqualitative inquiry to conceptually focus on an impersonal production of care. The author shows how care emerges in the between of children and forest in an outdoor learning environment and highlights what it continually produces. She concludes by discussing the need for a conceptual evolution of "care" in the philosophies of environmental and outdoor education.

Key words: care; children-forest; collective; process philosophy; outdoor education
In the voluminous humanist philosophy, "care" in its basic sense is often conceptualized as a wilful act of support and attention from one subject to another or to self (e.g., Hume, 1975; McNeil, 1951). It has been profoundly developed by the feminist tradition theorizing ethical and political aspects of care (Gilligan, 1982; Held, 2006; Langford, 2019; Larrabee, 1993; Noddings, 2003; Puig de la Bellacasa, 2017; Pulcini, 2013; Tronto, 1993). Among them, the problematics of care in education (e.g., Noddings, 2005) have adequately occupied a prominent niche. However, a large fraction of these discussions still revolves around an understanding of care as a human- or subjectguided act. This paper aims to zoom in to one of the challenges of theorizing care-a scarcity of educational discussions about care in its morethan-human form (Haro Woods et al., 2018; Hohti \& Tammi, 2019; Puig de la Bellacasa, 2017). In this article I invite the reader to explore care beyond its subject-guided manner and imagine it more as a collective practice, neither exclusively human nor nonhuman.

To see how care is enacted through a collective effort in education, I suggest approaching the conceptual imbalances born out of stewardship-oriented environmental education (Blanchard \& Buchanan, 2011; Taylor, 2017) from the perspectives of posthumanism (Malone, 2016; Rautio, Hohti, Leinonen, \& Tammi, 2017; Snaza \& Weaver, 2015; Tammi, 2019), new materialism (Barad, 2007; Bennett, 2010; Braidotti, 2013), and process philosophy (Deleuze \& Guattari, 1987; Manning, 2014; Massumi, 2015; Whitehead, 1978). Accordingly, in addition to talking in terms of targeted care-of, about, or for nature-I offer to talk about the force of care in-between in order to expand this notion toward its more-than-human diversity and subjectivity and to see it as an effort of multiple organisms. In doing so, we need to view care through the lens of the existence of the world rather than that of an individual and notice how such care-a force emerging in the between of subjects—contributes to the sustenance of life.

Focusing on the early childhood outdoor education context of Finland, this paper delves into an idea of care in the engagement of preschool children and the forest. In particular, I concentrate on what is being produced within children-forest dynamic encounters when they are being viewed as events of care. Furthermore, I am interested 
in briefly discussing the need for a conceptual inclusion of care in-between in the philosophy and principles of environmental and outdoor education.

Thus, I ask, What is being produced in the encounters of children and forests when they are being conceptualized as events of care in-between? By answering this question, the paper aims to contribute to the discussion across new materialist approaches with a specific focus on the aspect of coemergence in children's embodied relations to a place-which, hopefully, also complements the studies in environmental philosophy focusing on the issues of speciesism and the ethics of environmental protection.

To respond to this research question, we need to explore a few theoretical concepts that will assist the reader in better understanding the phenomenon of care in-between. However, I will first need to explain what led me to these concepts, or, in other words, how my postqualitative inquiry (St. Pierre, 2011) has evolved.

\section{Process of inquiry}

All ideas in this paper were gradually transforming as I was both reading and writing during and after the empirical part of the study. The role of fieldwork in this paper is to propel the conceptual arguments and highlight insights; as is common in postqualitative research, theory and data are not separated but are treated as a coevolving process of inquiry (e.g., Jackson \& Mazzei, 2012).

During my fieldwork, which took place in a Finnish kindergarten, I chose to follow posthumanist and new materialist approaches (Barad, 2007; Braidotti, 2013) to stay in search of what might exceed the limits of my deeply rooted humanist perception (Diaz-Diaz \& Semenec, 2020). In posthuman education research (Snaza \& Weaver, 2015; Taylor \& Hughes, 2016), the researcher's task is to learn to be affected by and attune to a collective field of relations (Ringrose, Warfield, \& Zarabadi, 2019). As highlighted by Arno Boehler in a conversation with Erin Manning (2016), one should be able to "open up a space in which another form of relationality with other nonhuman things becomes possible” (p. 192; also see Kahn \& Kellert, 2002; Louv, 2008).

The extensive scholarship on body-place entanglement of children and nature (Common Worlds Research Collective, 2019; Crinall, 2019; Crinall \& Somerville, 2019; Hackett \& Somerville, 2017; Rautio, 2013, 2014; Tammi, Rautio, Leinonen, \& Hohti, 2018; Thiel, 2018) made me consider children's bodily movement as an increasingly relational way of becoming. The above-mentioned studies suggest that what a child's body can do and invent is always informed by the world.

This idea settles in a certain incongruence with the theory of affordances (Gibson, 1986), whereby a child can do only those things for which an environment has a capacity. For example, the ground affords only certain movements, like crawling, running, lying, or digging. Therefore, the possibilities are limited to what the ground offers as if they were somewhat inherent properties of the world (Oliver, 2005)_ready-made aspects people can experience. However, this theory is bereft of any immanent creativity of the world, where the world is an experience itself (Whitehead, 1978). It evolves simultaneously with a child-forest creative engagement that proves to go beyond the list of predefined actions (Diaz-Diaz \& Semenec, 2020).

Accordingly, all this cumulative knowledge motivated me to explore ways of noticing events that form spaces where difference and creativity thrive. One of such ways is to think of child-forest encounters as events of coemergence.

Coemergence of children and forests

"Child" and "forest"1 look like discrete categories on paper-in their official definitions in dictionaries, policy 
documents, and discourses-but as life moves, we recognize that stability is only a matter of perspective. Speaking in fragmentary terms, children always produce and are being produced by culture, family, objects, the weather, intentions of the teacher, curricula, and modes of organizing childhood per se (Murris, 2016; Prensky, 2001; Prout, 2000). Likewise, an understanding of "forest" as an agentic self (Kohn, 2013; Scarfe, 2018; Whitehead, 1964, 1968) thrives beyond the seemingly separate forested areas. Lives of forests are complexified through the emerging political and affective ecologies as well as global ecologies of living and nonliving things traversing vast layers of terrestrial, subterranean, and atmospheric spaces (Grace, Berninger, \& Nagy, 2002; Kosek, 2006). Notably, children and forest produce each other daily (Myrstad, Sverdrup, \& Helgesen, 2018; Pacini-Ketchabaw, 2013). In the new materialist tradition, it is called coemergence.

By the coemergence of children and forest I understand their dynamic coevolvement that corresponds with a poststructural idea of being as becoming (Deleuze, 1994; Rae, 2014), where being is a process of multiple becomings that constitute the world's continuous process of forming and organizing self. So, a being here refers to the being of a world rather than an individual one-the life of the world, its existence. In Elizabeth Grosz's terms, it is "always more than itself insofar as it is also the site of becomings without end, becomings that keep it 'alive' ... keep a being from remaining the same as itself" (2017, p. 260). The coemergence of children and forests is one of such multiple becomings in this process of life formation.

In the philosophy of Alfred North Whitehead (1978), life is also a process that is "in the intervals between things-in the way things relate, in the way they come together in events under the dominant tendency towards the generation of new forms, or ontogenesis" (Massumi, 2015, p. 183). Correspondingly, children and forests "come together" in events-durations - to form a becoming of our life or potentially something new that arises from the in-between of their relations through the force of care. What their encounters generate can never be reduced to their mere categories. Instead, their production of each other falls under the category of speciation (Manning, 2013) or the emergent subjectivity of both child and forest, their ecology, which I further elaborate on in this article.

\section{In search of the approach to children-forest craft}

During my fieldwork I, as a researcher, could not observe with my available sensory apparatus the mutual production of children and forest; I could only think of their encounters as such. Yet what I observed is the creative capacity of children and forest to always generate more-new unusual structures, unheard sounds, spaces of difference, and unpredictable movements - which allured me. Simultaneously, I did not know how to approach this collective craft of more and theorize it. I decided to try and think with theories (Jackson \& Mazzei, 2012).

Thinking with theory, or with concepts, according to Jackson and Mazzei (2012), is a way of attending to data. Various authors have suggested that data might reveal new meanings after a researcher views them across multiple perspectives. In search of theories to augment my data, I found the scholarship of Erin Manning $(2013,2014,2016)$ and Brian Massumi (2015), specifically their theorization of care and excess. From then on, I thought with their nonanthropocentric theories and approached data through a diffractive reading/writing (Barad, 2007).

Diffractive reading, or "reading insights through one another" (Barad, 2007, p. 25) allowed the collective craft of more, as a "broad light beam" (Björkman, 2005, p. 39) to be "diffracted into several stories" (p. 39). I started to experiment with writing as an outside voice. Hence, Brita-a more-than-human character-came into existence as a narrator of these stories. Apparently, it was only through a diffractive writing (Barad, 2007) - an iterative, insightful, abandoned then retrieved process of remaking the written text-that I thought of many ideas for this paper. Through both reading and writing I realized how the relational movement of children with forest, their creativity in the world, can be conceptualized as events of care and theorized further in relation to the context of 
environmental and outdoor education.

In other words, the actual fieldwork visits were just one of the elements enriching my "conceptual co-meditation" (Crinall \& Vladimirova, 2020, p. 31) with theories and layers of data toward the notion of care in-between. Brita's voice served as a tool and a way to postqualitatively (Lather \& St. Pierre, 2013; MacLure, 2013; St. Pierre, 2011; Ulmer, Nordstrom, \& Tesar, 2017) conceive what might be conceptually produced by writing when it comes on the verge of human and nonhuman narration. Respectively, Elizabeth Adams St. Pierre (2019) encourages postqualitative researchers to experiment with inquiry and create it anew. My reading-writing-thinking process materialized as Brita, who shares with the reader her memoirs of children-forest encounters and speaks about them as events of care in-between.

Where events are rhythmic durations constitutive of life, any duration, according to Henri Bergson (2000), can materialize only retrospectively, thus through memory. In that sense, memoir as a genre is a way to produce the data in their spatial duration. Therefore, Brita can speak of events only as memories. Speaking from the future, she reminds us of the events of care in a nonlinear manner to emphasize the continuity of the process of care inbetween, irrespective of its temporal-spatial reference and without attachment to one species.

Next, I describe the data and the data collection process, then I will outline the major theoretical concepts. Finally, I offer a series of Brita's memoirs and a space for discussion.

\section{Data}

As introduced earlier, the role of empirical data in this paper is to propel conceptual development. Actual fieldwork is an essential part of this study even if it is not handled in a conventional way and taken as a sole source of derived information. Conceptual thinking does not take place in a void, hence the fieldwork surroundings in which the insights of this paper emerged are described here in detail.

I had been visiting the municipal kindergarten with outdoor specialization for five months in 2019. It is situated in the north of Finland, at the heart of a pine forest near the shore of a huge bay. It has four early childhood education (age 2-5 years) and three preschool (age 6 years) groups. One of the preschool groups, however, is called an outdoor preschool group (OPG) or metsäeskarit in Finnish (literal translation: forest preschool kids). As soon as I learned about this place, I contacted one of the OPG teachers and asked for a permit to visit. The visit was a starting point for developing an actual study. There were 12 children and two teachers in this group at the time of my visit. It was the first experimental year of an outdoor program where teachers organized four-hour trips to the nearby forest on an everyday basis.

I came to the OPG with a sincere intention to raise awareness about a forest in Siberia that is being littered. I planned for us to engage with this forest through soundscapes and storytelling. Yet after a few visits, my intentions lingered in accord with a strong urge to be open to unscheduled processes. What sparked my interest during the first meeting was the organization of the day. It was a structured improvisation, whereby teachers offered the potential activities of the day, followed by a space for discussion, and ultimately, children and teachers made a collective, often open-ended decision.

During my visits, I observed and participated in the outdoor group activities and walks; I made videos, pictures, interviews, and audio recordings. While the data collection appeared traditional, the approach in this study lacked the conventional preparedness and planning. Each of my visits was filled with anticipation of something that could not be known beforehand, something that I would not meet otherwise. I participated actively by unsettling and 
disordering my own attitudes (Pacini-Ketchabaw, Taylor, \& Blaise, 2016) toward the multispecies happenings in the field and by noticing something curious (Haraway, 2015), something that might "glow" (MacLure, 2010). The conceptual tool of "glowing" was useful for noticing moments of creativity in the children-forest encounters. As I explained earlier, these moments brought into focus something new, something I had not yet seen, something that "bulged" at the background of all the other data.

My role as a researcher was one of a friendly observer and a learner. The children and the adults of the group were aware of being part of a research study. I was there to observe, absorb, learn, and then proceed with materialsthoughts - to work on a conceptual level.

Importantly, I was doing the conceptual work both during and after the fieldwork period. Apart from data collected in the preschool group (videos and photos, my notes, daily conversations, utterances, drawings, songs, symbols, hopes of the teachers, brochures), I engaged with other types of data in the study. Accordingly, they are historical texts that described the everyday life of my fieldwork place, a geopolitical location of the region, my own memories of living in Siberia near/with taiga forest and sensory perceptions at the time of visiting/reading/writing, and my talks with research colleagues. I used all these cumulative data for my thinking with theories and a diffractive reading/writing process of the inquiry.

In the following section I cover the main theoretical concepts—care, excess, and speciations—that emerged during this analytical process.

\section{Theoretical concepts}

The concepts I describe further encapsulate the idea of care in-between and represent phenomena that, in theory, coevolve together. I outline the terms separately for the purpose of a convenient reading, but the reader might recognize each of them in every section as the theoretical introduction proceeds.

\section{Care as an existential concern}

Apart from a targeted manner of support and provision of safety from one subject to another, care is also known as an existential state ${ }^{2}$ animating the movement of physical bodies (Heidegger, 1962; Derrida, 1997), as something that orients one's movement across life. For instance, Martin Heidegger (1962) in his early work saw care (Sorge) as a structure of a human's being that informs people's anxiety as they face the fear of temporal existence on Earth. Care in Heideggerian terms is therefore a temporality, a compulsion of a man "to be 'lived' by the world" (Heidegger, 1962, p. 240). Jacques Derrida (1997), on the other hand, while not being very systematic at using the notion of care, still talked about auto-affection (affect of self), which automatically implies hetero-affection (affect of others). In plain words, this means that thinking of self is simultaneously thinking of others and vice versa, which could be considered as a caring state.

In the phenomenology of Heidegger (1962) and Derrida (1997), the idea of care is cultivated within the humancentric ontology and always strives to find its empirical application in the material world, always pertains to an experience of a person. Accordingly, Heideggerian care in most of its interpretations remains quite humanistic, with no clear deconstruction of humans, or as Lisa D. Campolo (1985) suggested, not necessarily imbued with antihumanist values.

Alternatively, Manning (2013, 2014, 2016) and Massumi (2015), following Whiteheadian process philosophy, developed a different-nonanthropocentric and onto-epistemological-account of care as an existential process. They theorized "care for the events" or event-care, which I rethink in this paper in relation to the children-forest 
encounters. According to both authors, life is a process made of events and the world emerges through the event's concern or care. Event cares for giving itself birth. Care here is the intensity of the world producing self and differentiating. Essentially, care does not belong to someone but to everyone in the field of encounter. It gathers its strength in the between of both humans and more-than-humans, from their relational field. That is why I formulate care in the paper as care in-between.

Care in-between is not synonymous with life. Rather, it is a force by means of which life differentiates in a passage to something new or not very new. Since the world, according to Manning (2013) and Massumi (2015), emerges through both a habit and a chance, every event's concern might actualize as a habit that is simultaneously open to a potential to become other-than-itself. To put it bluntly, it means that many pasts of the world (forms, patterns, phylogenesis) are reactivated again and again in events, but if care in the relational field is strong, the world gives birth to new forms of life. Therefore, events differ by the degree of care. If it is strong, we might witness the appearance of "more" - something original, something we have not yet observed. If the modality or degree of care is not as strong, on the other hand, we spot the habit, inheritance of the past, or something we can predict.

In education, the strength of care in-between depends on the degree of openness and stiffness of the structure. Care generates new forms of life and creativity in places of nonrigidity. If the structure is ossified and improvisation is not allowed, there is no room for differentiation and the in-between field emerges as a habit, a reproduction, and a recurrent quality. To become different means leaving the comfort zone and being ready to risk, change, become open to something unconventional, not know the outcome. The forest group I visited is one example, where structure often cohabited with improvisation and, of course, trust: Children walked on ice, climbed high, imagined the activities for the day, and played without planning, while learning to read and write with whatever could be found in the forest.

\section{An excess of life}

Massumi (2015) further explained the account of care. He argued that care is "a holding together of elements as they are taken up in the production of an effect that exceeds their simple plurality, there is an emergent relation that makes the separate elements immediately concern each other" (p. 197, emphasis added). "Excess" here corresponds with the quality of "more" I talked about earlier. To unfold the meaning of this definition, I will describe it with an example.

Like all examples from fieldwork highlighted in this paper, the following one is presented as a selected illustration. A fitting description to aid the reader in following the conceptual threads. The following was an event of the appearance of a virtual heart-a heart that was simultaneously present and not.

On a perfectly warm winter day $\left(-3^{\circ} \mathrm{C}\right)$, when snow had its sticking qualities, teachers, children, and I went for a forest trip. After a long walk, one of the teachers offered that the children should make a snow castle together. She gave them several wooden block shapes, which they immediately started filling with snow, trampling it down to finally get many rectangular-shaped snow blocks. Without prearrangement or planning, many children, teachers, and I were crafting these blocks, laying them side by side, one after another, running up and down. No leadership, no planning. Everyone was responsible for laying the snow blocks only in relation to the ones previously laid. It, being a spontaneous engagement, emerged in the form of a heart (see Figure 1). We noticed it only after the snow castle was ready. It felt like, "Wow, it worked out!" 


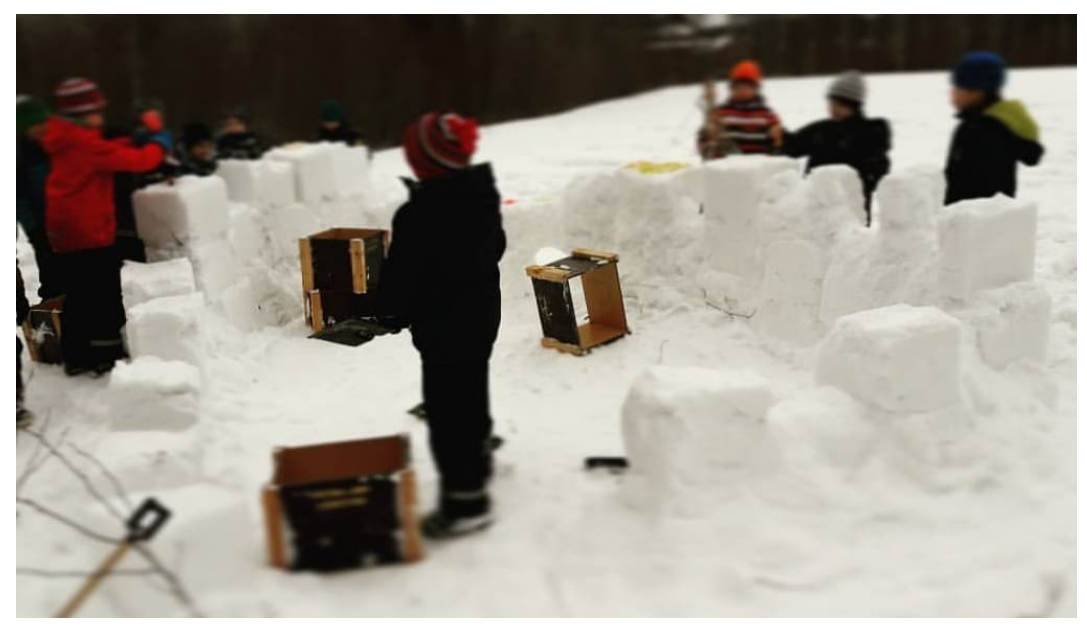

Figure 1. A heart event.

We happened to emerge together on a plane of the event in a way that the event's concern became visible or was strong enough to be felt. The heart was only virtually there because the blocks landed in such a way that the heart popped up. So, the blocks concerned each other only in the event of the heart's appearance. The heart is an unpredictable effect that exceeded the plurality of bodies-in-the-making. It was registered through a feeling of excitement: "Wow!" The "wow" exclamation points to the "more" value created in this event, something we had not observed before. It was something extra, an excess movement directed forward (Manning \& Massumi, 2014). The intensity of this movement may come with the potential for new forms of life- "the as-yet-unseen, the as-yetunthought, the as-yet-unfelt" (Manning, 2016, p. 23).

In the context of environmental and outdoor education, the excess may arrive in different forms: a song, a shape, an utterance, a built structure, a drawing, or something unexpected. However, "excess" does not necessarily mean something surprising, something that can be felt, or something we could not have imagined. Excess as intensity also manifests itself in the micro movements we do not usually pay attention to (see the child-branch event below).

The virtual heart here is an excess of the moment, a new and unfelt-before subjectivity of the unique event. It is the subjectivity of care in-between, which arose with the event of a children-forest collective craft ${ }^{3}$.Manning (2013) calls this caring subjectivity speciation, or "a species of event" (p. xviii).

I explain her theorization of this idea below.

\section{Speciation}

According to Manning (2013), speciation is not about species defined as discrete categories like Homo sapiens or Pinus sylvestris. The speciation process is also not synonymous with "speciation as the evolutionary process by which new biological species arise" (Manning, 2013, p. 229). Speciations are rather intensities, or relational movements of bodies that are species-not-yet, thus in the process of formation. Manning (in Massumi, 2015) argued accordingly as follows:

The point is not that there is no identity-no human, no animal, no plant-but that the species is not where the process begins or ends. Our proposition is not to negate species or identity, but to become aware that the force of speciation, of collective individuation, happens in the interstices where the ecologies are still in active transformation. (p. 123) 
This means that children and forests (its denizens) do exist as distinct entities, individuals, or species with a number of characteristics. We are all in categories as long as life requires us to be stable and rational, following a predefined route of development. Yet it is just one plane of existence. On another plane, children and forests produce each other, shaping a less definite becoming of life. They move daily as speciations, or as more-than-species bodiesin-the-making-forces "always in excess of a given species" (Manning, 2013, p. 196). They are dynamic in-thebetweens of children and forest, which is a collective moving forward.

For instance, in an encounter of a child climbing down a tree (see Figure 2), the branch-child speciation ${ }^{4}$ comes in many iterations, each of which is a unique instance of it. The first bounce of a branch offers a new existential opening toward another iteration of this speciation-balancing-vibrating. The second bounce-balance proposes determination for jumping-recoiling, where the branch is in the transition of springing back and the child is in the transition toward jumping. Before we name them jumping and recoiling, respectively, there is always a determination for more, a desire for more life at the intersection of species-not-yet. It is not a branch's determination or a child's determination per se; it is an event's determination to care for difference and continuity.

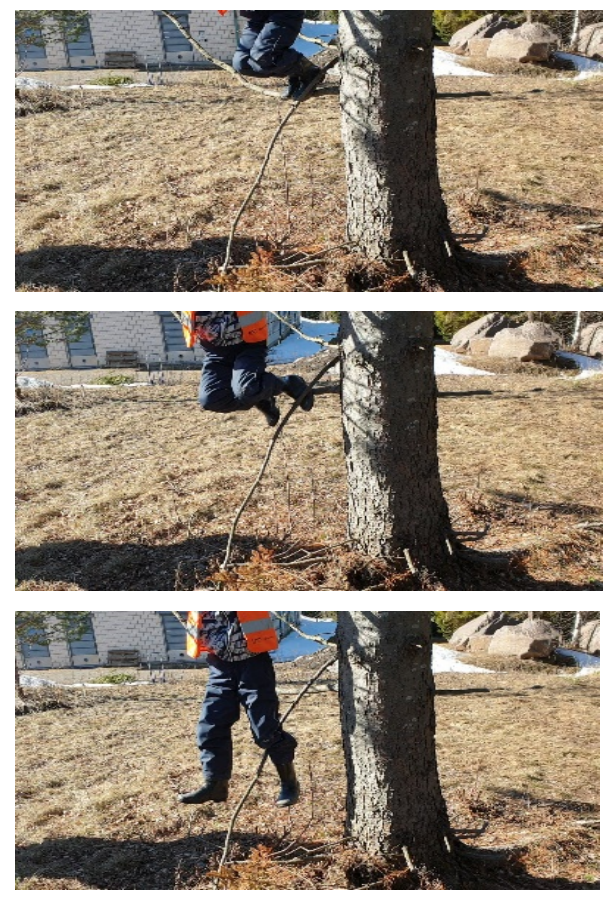

Figure 2. A child climbing down a tree.

The force of care "blends" the intensities of the subjects, so to speak, and creates a sense of belonging to something above their respective subjectivities in a transition toward another event. ${ }^{5}$ Excess here comes with the tendency of a "transition toward...", or a continuity of the child jumping down. Habitual as it might seem, this event carries, however, a weaker degree of concern as compared to the event of the heart's appearance, because we can predict what comes next.

\section{A conceptual summary}

So, life's creative capacity, its existential value of a continuous differentiation can be amplified through an abundance of events of care in-between. Speciations of children and forest emerge in these events with a proposition for excess, which altogether counts as a production of life. By creating something extra, children and forest not only contribute 
to the becoming of the world but also intensify each other's existence. They do so via care creating a relational milieu that belongs to everyone. In fact, care in-between mobilizes the politics of belonging, where everyone concerns each other and everyone makes their contribution, which cannot be considered better or worse, more or less. It is a contribution of its own, a singular input of the collective subjectivity.

This is an important message of this paper, which is needed for conceptually expanding the idea of care in education in its beyond-subject form. It also responds to my research question "What is being produced in the encounters of children and forests when they are being conceptualized as events of care in-between?" This response, however, needs to be enriched and elaborated through a series of diffractively produced memoirs of Brita, which follow next.

\section{Memoirs of children-forest speciations}

As I mentioned in the beginning, Brita shapes this part of the paper by her memories (in italics below). She is not a whim of imagination carried by a fabulation to entertain a reader. Her emergence is a process of inquiry. Like a virtual heart from the aforementioned example being the emergent subjectivity of children-forest craft, Brita (and her stories) is the emergent subjectivity of all data's diffractive encounter. In that sense, Brita's image is the result of care in the between of data. This means that all material-discursive practices, human subjects, children and adults, as well as nonhuman entities present, for instance, the forest surroundings and inanimate objects, have a stake in Brita's existence. I, as a researcher, was the sounding board for Brita's voice, which I analytically amplified through a diffractive approach to data turning into words in this paper.

Postqualitative inquiry enabled me to balance "individuality and deindividualization" (Rautio, 2020, p. 2) and to write Brita into this paper as a plurality of voices that have no skin colour, no date of birth and passport, no well-defined identity or ability to unlock a smartphone with her irises. Yet she speaks; she has you and me as her listeners; she cites the theories and physically moves - as an individual-through this life. It does not matter what she looks like, or what or whom she represents, but rather what she does for this paper.

Apart from birthing the ideas for the paper during my writing process, Brita assisted in making the diffractively produced, seemingly separate stories a part of a bigger narrative with its events being in the transition toward one another. Some events concerned the remote past, and Brita stepped in as a deep time reckoning expert (Ialenti, 2020) of those changes to show how care in-between moves across "different scales and intensities of time" (Manning in Massumi, 2015, p. 123). It is important because the stories hint at how even micro movements of children with nature we do not usually attend to produce the bigger processes of a global scale, our futures and movements-to-come. Moreover, Brita's stories build a bridge between the theoretical concepts I discussed and their manifestation in daily life.

From time to time I, as a referential listener, "plug in" to the stories by leaving the in-text notes (in roman text after the italics) to analytically assist Brita in threading characters in this cowriting.

Between...

I've always loved the sea. Sea is who loves me. Sea is ... my song, my dress, my skin. My father was kapteeni, a captain of the ship Verna. Whenever he returned from a work trip, I ran toward him: Isä! Iskä on tullut! (Father! Daddy came!) Once, in April 1791, he brought, among other things, a giant ostrich egg from England. It was huge and empty. Just an eggshell. I stared at it, trying to imagine a chicken who would brood it.

When my father was on holiday, he always took me to the pitch mill. In those days, you could make a fortune from the production of pine tar, and almost every household produced some. While Finns had been selling it extensively to 
Stockholm, my father, as a part ship owner, also used it as a water repellent for the wooden Verna.

Interestingly, the pitch ${ }^{6}$ mill was in the same place where my kindergarten was later built. At the beginning of the 18th century, it was still an island, as my father told me and I witnessed myself, but in the course of just 100 years, it became a peninsula due to the land uplift. I wonder what it could mean for an island to turn into a part of the continent in a such relatively short period of time?

Indeed, Finland is one of the Nordic countries that experience a phenomenon called postglacial rebound (Farrell \& Clark, 1976; Johansson et al., 2002). In the 18th century, there was a massive elevation of land (more than a metre a century) as a result of deglaciation, or the Pleistocene's ice age glaciers melting after pressing the Earth's crust for 2.58 million years (Benn \& Evans, 2010; Lambeck, Yokoyama, Johnston, \& Purcell, 2000). As Pippa Whitehouse (2014) explains, "the meltwater from the ice sheets flowed into the oceans, and the land which had been beneath the ice began to rebound upwards" (para. 3; see Figure 3).

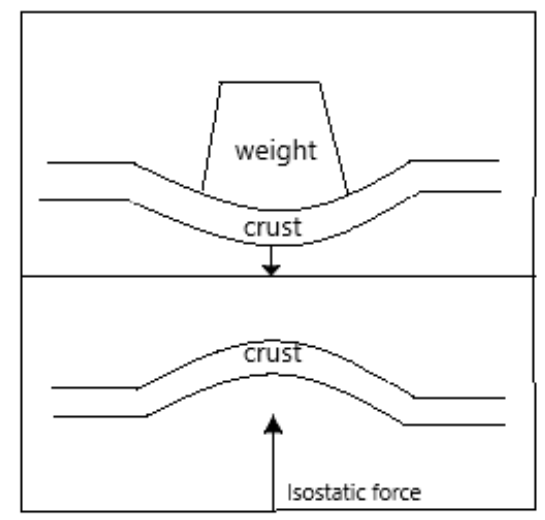

Figure 3. A postglacial rebound sketch

The "new" so-called land is not new from the perspective of its material existence. Rather, its tectonic surface in relation to the continental crust has transformed, "popped up" from the sea and started a "new" life ashore. This surface is continuously changing through forces of moving speciations-of land-ice-human-nonhuman coevolvement-shaping the world.

We crossed the bay area between the mainland and the island. While Father was talking with the workers of the mill, I rushed to the coast. How strange it feels to see Pekka — my kindergarten mate-in this image (Figure 4) lying by a stone, the same stone that was, perhaps, half a mile away from me, under the water in 1773. 


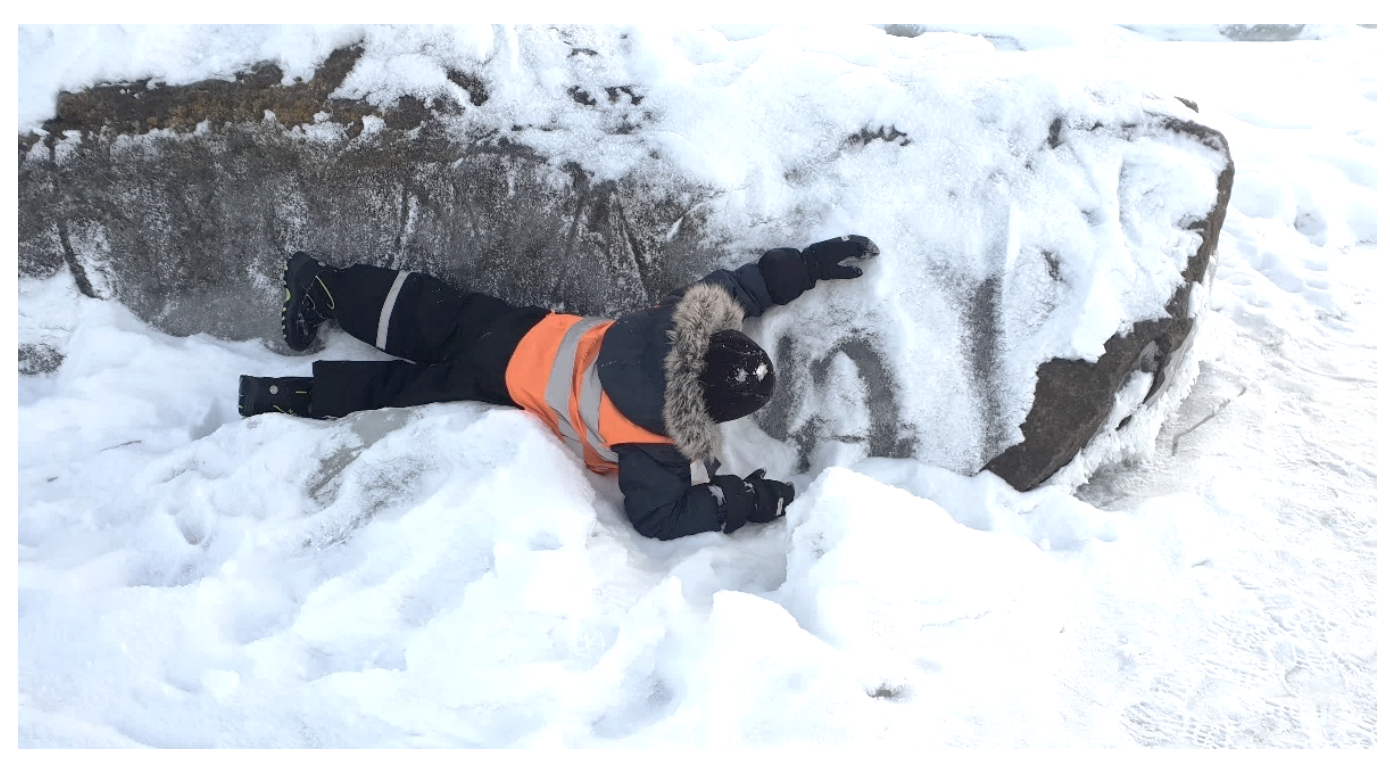

Figure 4. A stone-child event.

I was there palpating joy of the "recently" emerged stone as if it were a newly appeared birthmark on our collective body of island-mainland-forest-people-pitch. Our collective body cherishing its marine acquaintance-smelling of ostrich eggshells, sea routes, salty water, and tar-coated wood-with the terrestrial. Little did the stone know, while in the sea, that its relations with the sea creatures would morph into a different set of relations with terrestrial Pekka, relations that otherwise could not have been born. His movements with/around the stone-drawing, climbing, brushing off snow, hitting it with a hammer, lying next to it, looking at it-felt like a conversation with someone familiar, a dialogue emerging from in-between centuries and minutes. Where does this dialogue travel to?

...two and...

I recollect times I was attending a forest preschool.

My friend Jaakko and I, we had a secret. We buried a few animals in the forest. The very first animal we buried was a swan. It was huge and we felt pity for it. Jaakko and I put it on the stone and covered it with grass. I don't know how we knew that we should have a ritual. It was scary, but it felt very important. Another time we buried a vole: just dug the ground and put it there. After that, I laid upon the top of the grave a small stone, like a memorial board. Jaakko changed it to a bigger one.

Children who bury a swan or share with it a mourning moment by placing grass on it are part of collective practice, but not so much in the sense of three identifiable individuals (child, swan, grass) coming together. Rather, it happens in a transindividual sense, where everything in the field of encounter vibrates (Bennett, 2010), organizing the impersonal rhythms. Young children's urge to enact a certain ritual they have not yet been taught is not stored in the child, it exists in the relational movement of children with the world. This feeling emerged through the intensity of care that created an ecology of their concern with each other.

One day we went to a mountain (vuori) - it was one of our favorite playing destinations. It was not really a mountain in a sense, as we learned from the books. Rather, it was a chain of high snowbanks, forming hills distributed evenly along the forest road from both the right and the left sides. Snow in these hills was mixed with rubbish (straws and plastic) and soil. Teemu-our teacher-said it had been a storage place for snow collected from all over the city and 
carried there by street-cleaning machines.

In this naturally-culturally-formed environment we were moving together apart-at times growing as a group to roll a snowball down the hill or climb up on a snow plough; at other times we were in solo motion. With us and forests always already changing and being different, the day searched for more difference. It all looked like an adventurous and joyful collaboration called "the day cares"-or, as Teemu said in tune, "That's why we do it."

My teachers, Teemu and Teija, knew this feeling of togetherness. Apparently, it was their unofficial self-chosen pedagogical path-between togetherness and a rigid grip of a curriculum, which does not always unite, they often chose a group's mood. In the chaotic movement of children, snow, sticks, and other matter, they always felt a certain rhythmic flow, which made them adjust the activity. Once Teemu shared,

I find it important to follow the rhythm of children. I feel the group and I am open to their wants. The rhythm for me is a mixture of happiness, mixture of excitement, maybe it is sort of like, you know, those drawings where you have points one, two, three, four, five and you follow, you need to follow. It is like you have the same group, but today it kind of makes sense, it draws a picture somehow in your heart, your mind. That day, that moment. It is kind of like everything's working together, everybody's happy ... Maybe it's that "working together" thing ... it's like a team.

The "picture in the heart," as Teemu described it, corresponds in this paper with the virtual-actual appearance of excess. It does not happen every day so you cannot predict it, "but today it makes sense." The urge to move from one dot to another is caring in-between, resulting in the appearance of a picture. It is invisible to an educator's eye, but it is felt. Children might be doing different things at their own diverging paces, but when the whole field vibrates from their relational differences, we come to sensually perceive the collective modes of becoming.

\section{...more}

Brita shows an image (see Figure 5).

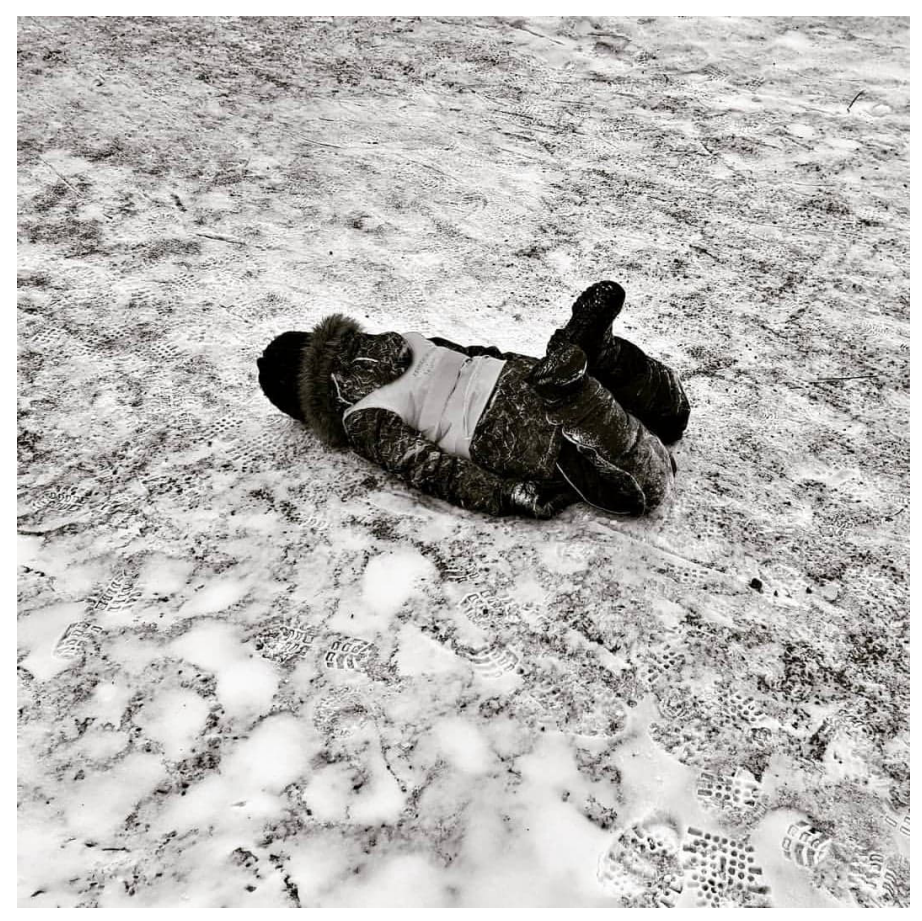

Figure 5. More. 
I like this picture because there is more to it. It is not just a person lying on the snowy ground (as Microsoft Word would offer to name it). It is first and foremost a rhythm, a movement, a potential and possibility, a collision of forces and energies in flow. There is something going on, something we do not immediately name, but we are open to its liveliness. The first question comes as "Why?" "Why is the child lying on the ground?" Let this question go. Leave this moment to itself-to speciate, to give to the world more of a life-feeling. Erin Manning would see in this image new forms of neurodiversity, being and doing, creating, rethinking, conceptualizing, and caring.

“The child must be tired. What if he gets cold?" one might think. This would not be wrong or right, it would be just one of the manifestations of care, the targeted care. Care in-between exists in another dimension of the worldly relations: at the intervals of the child and the ground, where none of them has chosen this way of being and lying. The vector of care brought them into this relational field of togetherness to concern each other the way we can sensually perceive it. Does the world need to slow down?

Apart from the felt virtual potential, children and forest speciate with propositions for new imaginary modes of living, which have already materialized symbolically (on paper), but not as real ones. They enter this paper through a memory of Brita:

"What is this?" Anna asked me when I was drawing a card of encouragement (see Figure 6) for the littered forest in Siberia. (Anna was one of the researchers who were visiting our forest preschool group.)

A berry-tree (implying I had drawn a little shrub with cranberry that usually grows in the Finnish forests).

Where did this berry-tree come from? From a fairy-tale?

I said I had known it from Jussi, my classmate, who was drawing little cranberry shrubs, lower than human height.

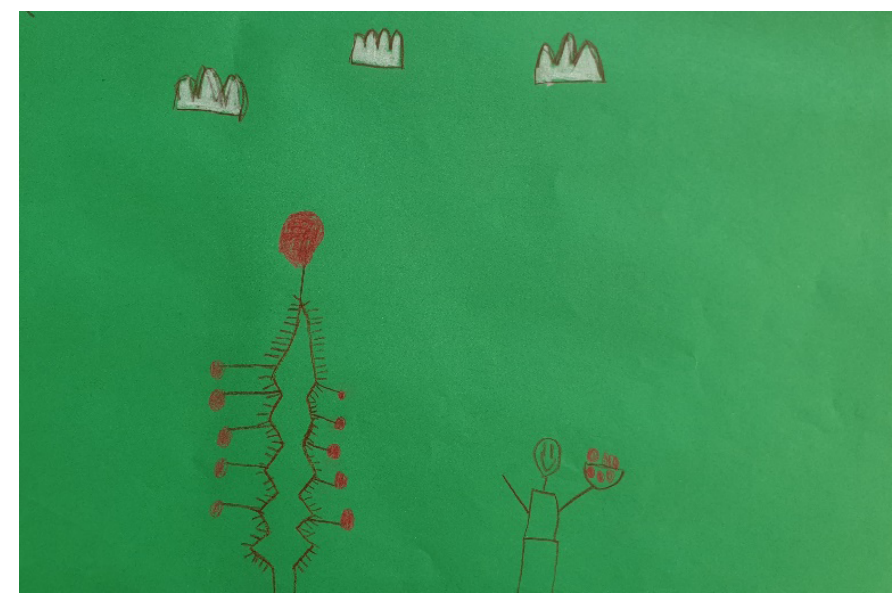

Figure 6. A berry-tree.

Anna found this image curious. As a tendency toward a berry-tree becoming, it was felt like a certain rhythm in the wake of the environmental crises that have flooded the earth. Could the cranberry tree, not a shrub, evolve elsewhere in Finland, or elsewhere in places yet-to-come?

Have a look at this one (Figure 7) - my classmate's drawing for the forest in Siberia-a child's bodily movement turning a subject of self (own name) into a wooden branch, a kind of a displacement of identity (Olsson, Dahlberg, \& Theorell, 2016). A transindividual child-forest-paper-crayons speciation is where "subjects become objects [objectsnot-yet] in a dissipation of the knowing self" (Preston, 2019, para. 4) and create more to this life with the potential 
toward a branch-child existence.

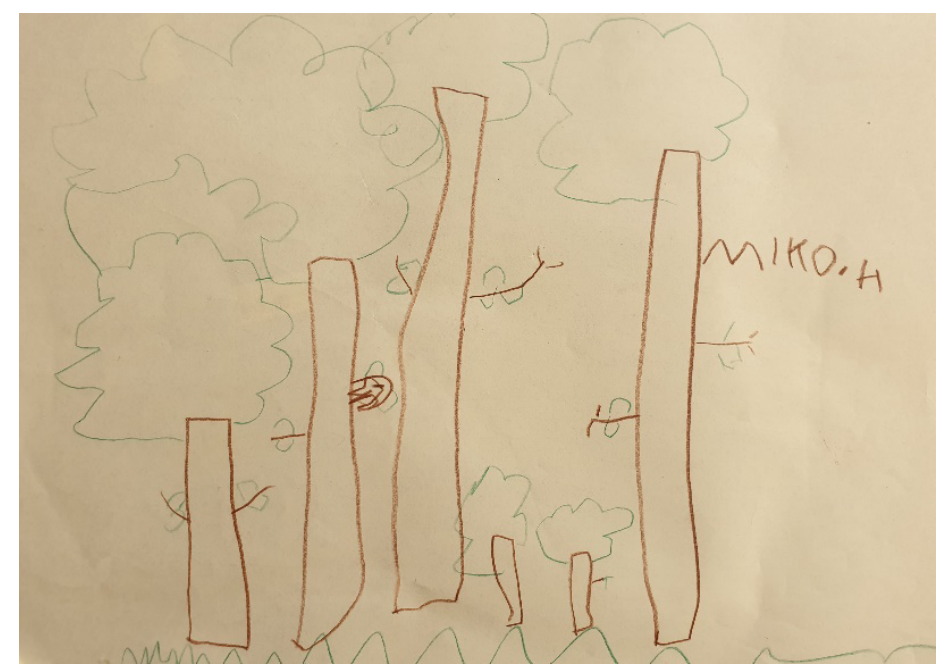

Figure 7. A branch-child.

Children with their "thinking-world" movements often direct our attention to places and instances of extra existence that we recognize-not-yet (Crinall \& Vladimirova, 2020). It does not mean that the world has a subjective intention of going there. Rather, its complex rhythmic flows might inform the unfolding speciations of children and forest about a possibility of the world changing the vector of its movement.

The ostrich egg my father brought me from England broke. The moment it broke I thought: "Can people save the world? That sounds like an end point. The (saved) world is not an ideal place we are going to. The world is a process that happens here and now. No one can save the world, but everyone can live this world. We live it, not for the purpose of saving it, but because it lives us."

Children-forest speciations create this world who lives them. The collective craft of children-forest entanglement (embodied conversation with a stone, tacit knowledge of burial rituals, or the need to slow down) guides us toward daily coemergence, collaboration, co-inventing, and ultimately, world living self. The world changes and lives because it moves by means of creating difference in-between two and more.

\section{Concluding thoughts}

This conceptual study, drawing on process philosophy and postqualitative inquiry, attempted to provide the reader with a glimpse of an idea of care in-between through an everyday engagement of preschool children and forests. By thinking with the notions of care, speciations, and excess offered by Erin Manning $(2013,2014 ; 2016)$ and Brian Massumi (2015), I have approached the idea of care beyond subjects and what it continually produces in the forest as a learning environment.

Along the traditionally known forms of care in environmental and outdoor education, where humans care for each other and nature, I suggested complementing these ideas with noticing another type of care-existential, impersonal, collective, determined for more life-and events it emerges with. In these events, speciations of children and forest-the in-betweens - not only produce our world but also intensify each other's existence. It happens through care creating conditions for their mutual belonging to one and the same field of their unfolding futures. 
If we think of integrating this type of care into the philosophy of environmental and outdoor education, we, by default, shift this idea from a realm of the world's life into a human-made dimension, where humans function in a framework of ethical principles, meanings, and moral values. Hence, I further discuss whether there is a need to establish the ethics of care in-between. Why might it be assumed that our education is lacking another definition of care or that the traditional idea of care is no longer enough?

First of all, this study does not aim to denounce care in its basic human understanding. By thinking about care with nonanthropocentric theories in this paper, I try to disengage, not from anthropocentrism as such, but from the very evident forms of human chauvinism and speciesism (Kopnina, Washington, Taylor, \& Piccolo, 2018) resulting from it. Humans care for something or somebody, and indeed, in the framework of care in-between it is more than accommodating. Caring for, sustaining self and others as a collective without normalizing the right to exploitation of others is what essentially works for the continual production of this world. In environmental and outdoor education, teachers' contribution through cultivating respect for nature, caring for it, and creating a variety of significant projects with children is crucial to the field. However, we need to expand the idea of care away from aiming to save the planet and more toward learning how to respond to its call to live in all its human and more-than-human intricate complexity. This reformulation shifts the position of humans from being saviours to being response-able (Haraway, 2016) individuals.

Second, by welcoming "care" as always already different-human, nonhuman, impersonal, and...—and by naming it so, we relocate the whole system of stewardship-oriented environmental and outdoor education into a broader and more inclusive plane of functioning. It then caters for a variety of living and nonliving matter organizing our life and education. On the downside, it might jeopardize the concern of a conceptual bias: By utilizing a variety of definitions of care, people will unintentionally start searching for the most effective one that brings tangible outcomes into their life. With the idea of impersonal care not being available to human vision, though, it might result in a major challenge.

Third, we need this conceptual evolution for rethinking the cultural definition of forest. Forest (nature) is not only a place for an aesthetic experience, learning, playing, or calming down (Board of Education of Finland, 2014, 2018) but also a thinking metaorganism that is encounter-able (someone we are still able to encounter) and who is co-caring with us for becoming together. It is a fundamental problem of human-nature dualism that drives humanity into a variety of ecological crises (see e.g., van Dooren, 2020). It amplifies the concern of our illiteracy in living with the world and surviving together rather than in opposition to each other. Notably, the idea of care in-between acknowledges a contribution of every element (element-not-yet) to the existence of the world, making them part and parcel of the caring process.

Finally, conceptual expansion might benefit the practices of both environmental and outdoor educators. In the expression of Joel McKim (interviewing Massumi, 2015), we can care for the events by modulating their emergence through the "creative limitations" (p. 78). From an educational perspective, this would mean balancing the structure and constraints with the rhythms of the day. Occasionally ${ }^{8}$ disrupting the institutional routine for the purpose of a "Wow!" effect might serve as an encompassing act of care-for children's well-being, teacher's planning time, pushing the limits of creativity, and eventually a global state of things. Furthermore, by caring for the events, we create more room where children can recognize that their movements are important and have value, not only for pedagogies (Land \& Danis, 2016), but for the emergence of life itself.

The suggestions for future new materialist and posthumanist research would be to continue exploring a dynamic multiplicity of more-than-human cares (Multispecies Editing Collective, 2017), how they might cohabit with the processes of human-guided care in educational settings, and what is needed to amplify their joint efforts toward 
creating an ecology of concerns. Furthermore, there is an urgent need to investigate the potential risks, ethics, and problematics of including a variety of cares in the curriculum and praxes. Finally, environmental education research will be able to contribute by conceptualizing a holistic, inclusive, and open-ended framework of different types of care, which will enable taking it to the level of policymaking and eventually making a meaningful educational transformation.

\section{Acknowledgments}

I would like to thank the reviewers and my colleagues who contributed by reading and commenting on the earlier version of this paper to enhance it to the current form. Furthermore, I am grateful to the participants of this research: always already emerging together children, teachers, and forests. I acknowledge the Naming the World Collective, whose ideas have shaped my work. Moreover, I cannot cite or mention all the sources for this article because they might reveal the place of my fieldwork, but with gratitude I acknowledge their prominent contribution.

\section{Funding}

This research is part of the project Significant Others-How Animals Matter as Part of Children's Everyday Life (AniMate), funded by The Emil Aaltonen Foundation.

\section{Declaration of Conflicting Interests}

The author declares no potential conflicts of interest with respect to the research, authorship, and/or publication of this article.

1 Forest in this paper is contextualized within a general image of the boreal forest biome, the largest land biome in the world, which extends across the northern hemisphere (from Alaska to Finland and northern Japan). Yet for the purpose of this study and my research, a forest is defined as a living metaorganism and a porous entity with seemingly fixed but changeable boundaries, just like human beings are (Frost, 2016; Glick, 2018). Therefore, its cultural definition is also mutable in relation to humans and their activities.

2 The idea of existential movement, or what informs life's formation and how, has been a focal point of philosophical discussions for centuries (explored by Aristotle, Plato, Kant, Hegel, Heidegger, Bergson, Ruyer, and Deleuze). The absence of these debates would imply an indubitable answer to the origins and meaning of life, which I do not directly concentrate on in this paper.

3 The idea of "children-forest collective craft" dwells within the bigger picture of outdoor education as a system of practices and discourses. Instead of being excluded, teachers, schools, organizations, and researchers are always already constitutive of what I mean by childrenforests in the educational context.

4 This is a reductive example (like every other example in this paper), for there are multiple cocreators of this event: teachers who talk to the child, air, elements of clothes, boots that create a certain kind of rubbing effect with bark, and more. It is a complexity of multiplicities, which lies beyond any written elaboration.

5 If a child falls off a tree while climbing down, it is also a creation of difference and more-to-this-life that on a plane of care in-between is neither good nor bad. Care in-between in this sense is a neutral force. It cannot be labelled in terms of moral values, because in this way, it will be a judgment of an outsider, a representation. The traditional care has positive or negative connotations because it functions in the value-laden human realm. Care in its existential state is neither positive nor negative. In this article, positivity is rather synonymous with continuity and enhancement of life.

6 Pine pitch, as tar's subproduct, has been used in sealing and mast varnishing by mariners for at least the past six centuries.

7 All the children's and teachers' names are pseudonyms. 
8 "Occasionally" here refers to an idea of Massumi (2015), who argues that “life can't always live at the limit. It can't continue to survive if it is always pushing to the limit of intensity, creating new forms. It needs a degree of stability, oases of rest" (p.183). This means that modulation of events is a matter of spontaneity rather than of everyday planning. 


\section{References}

Barad, K. (2007). Meeting the universe halfway: Quantum physics and the entanglement of matter and meaning. Duke University Press. https://doi.org/10.1215/9780822388128

Benn, D., \& Evans, D. (2010). Glaciers and glaciation. Hodder Education.

Bennett, J. (2010). Vibrant matter: A political ecology of things. Duke University Press. https://doi.org/10.1215/9780822391623

Bergson, H. (2000). Time and free will: An essay on the immediate data of consciousness. Kessinger.

Björkman, C. (2005). Crossing boundaries, focusing foundations, trying translations: Feminist technoscience strategies in computer science [Doctoral dissertation, Blekinge Institute of Technology]. DiVA. http://urn.kb.se/resolve?urn=urn:nbn:se:bth-00296

Blanchard, P. B., \& Buchanan, T. K. (2011). Environmental stewardship in early childhood. Childhood Education 87(4), 232-238. https:// doi.org/10.1080/00094056.2011.10523184

Board of Education of Finland. (2014). Esiopetuksen opetussuunnitelman perusteet [Basics of the preschool curriculum]. https://www. oph.fi/sites/default/files/documents/esiopetuksen opetussuunnitelman perusteet 2014.pdf

Board of Education of Finland. (2018). Varhaiskasvatussuunnitelman perusteet [Basics of the early childhood education plan]. https:// www.oph.fi/sites/default/files/documents/varhaiskasvatussuunnitelman perusteet.pdf

Braidotti, R. (2013). The posthuman. Polity Press.

Campolo, L. D. (1985). Derrida and Heidegger: The critique of technology and the call to care. Journal of the American Academy of Religion, LIII(3), 431-448. https://doi.org/10.1093/jaarel/LIII.3.431

Common Worlds Research Collective. (2019). Children's relations with place publications. https://commonworlds.net/childrens-relationswith-place-publications/

Crinall, S. (2019). Sustaining childhood natures: The art of becoming with water. Springer. https://doi.org/10.1007/978-981-13-3007-0

Crinall, S., \& Somerville, M. (2019). Informal environmental learning: The sustaining nature of daily child/water/dirt relations. Environmental Education Research, 1-12. https://doi.org/10.1080/13504622.2019.1577953

Crinall, S., \& Vladimirova, A. (2020). Embodied motherly research: Re-birthing sustenance through the common (im)material. In L. Henderson, A. L. Black \& S. Garvis (Eds.), (Re)birthing the feminine in academe: Creating spaces of motherhood in patriarchal contexts (pp. 21-47). Palgrave Macmillan. https://doi.org/10.1007/978-3-030-38211-7 2

Deleuze, G. (1994). Difference and repetition. Athlone Press.

Deleuze, G., \& Guattari, F. (1987). A thousand plateaus: Capitalism and schizophrenia (B. Massumi, Trans.). University of Minnesota Press.

Derrida, J. (1997). Ofgrammatology (corrected ed.; G. C. Spivak, Trans.). Johns Hopkins University.

Diaz-Diaz, C., \& Semenec, P. (2020). Posthumanist and new materialist methodologies: Research after the child. Springer. https://doi. org/10.1007/978-981-15-2708-1

Farrell, W. E., \& Clark, J. A. (1976). On postglacial sea level. Geophysical Journal of the Royal Astronomical Society, 46(3), 647-667. https:// doi.org/10.1111/j.1365-246X.1976.tb01252.x

Frost, S. (2016). Biocultural creatures: Toward a new theory of the human. Duke University Press. https://doi.org/10.1215/9780822374350

Gibson, J. J. (1986). The ecological approach to visual perception. Psychology Press.

Gilligan, C. (1982). In a different voice: Psychological theory and women's development. Harvard University Press.

Glick, M. H. (2018). Infrahumanisms: Science, culture, and the making of modern non/personhood. Duke University Press. https://doi. 
org/10.1215/9781478002598

Grace, J., Berninger, F., \& Nagy, L. (2002). Impacts of climate change on the tree line. Annals of Botany, 90, 537-544. https://doi. org/10.1093/aob/mcf222

Grosz, E. (2017). The incorporeal: Ontology, ethics, and the limits of materialism. Columbia University Press. https://www.jstor.org/ stable/10.7312/gros 18162

Hackett, A., \& Somerville, M. (2017). Post-human literacies: Young children moving in time, place and more-than-human worlds. Journal of Early Childhood Literacy, 17(3), 374-391. https://doi.org/10.11771468798417704031

Haraway, D. (2015). A curious practice. Angelaki, 20(2), 5-14. https://doi.org/10.1080/0969725X.2015.1039817

Haraway, D. J. (2016). Staying with the trouble: Making kin in the Chthulucene. Durham, NC: Duke University Press. https://doi. org/10.1215/9780822373780

Haro Woods, Nelson, N., Yazbeck, S.-L., Danis, I., Elliott, D., Wilson, J., Payjack, J., \& Pickup, A. (2018). With(in) the forest: (Re) conceptualizing pedagogies of care. Journal of Childhood Studies, 43(1), 44-59. https://doi.org/10.18357/jcs.v43i1.18264

Heidegger, M. (1962). Being and time (J. Macquarrie \& E. Robinson, Trans.). Camelot Press.

Held, V. (2006). The ethics of care: Personal, political, global. Oxford University Press.

Hohti, R., \& Tammi, T. (2019). The greenhouse effect: Multispecies childhood and non-innocent relations of care. Childhood, 26(2), 169185. https://doi.org/10.1177/0907568219826263

Hume, D. (1975). Enquiries concerning human understanding and concerning the principles of morals (Repr.). Clarendon Press.

Ialenti, V. (2020). Deep time reckoning: How future thinking can help Earth now. The MIT Press.

Jackson, A. Y., \& Mazzei, L. A. (2012). Thinking with theory in qualitative research: Viewing data across multiple perspectives. Routledge.

Johansson, J., Davis, J. L., Scherneck, H.-G., Milne, G. A., Vermeer, M., Mitrovica, J. X., ... Shapiro, I. I. (2002). Continuous GPS measurements of postglacial adjustment in Fennoscandia-1. Geodetic results. Journal of Geophysical Research: Solid Earth, 107(B8). https://doi.org/10.1029/2001JB000400

Kahn, P. H., \& Kellert, S. R. (2002). Children and nature: Psychological, sociocultural, and evolutionary investigations. The MIT Press.

Kohn, E. (2013). How forests think: Toward an anthropology beyond the human. University of California Press.

Kopnina, H., Washington, H., Taylor, B., \& Piccolo, J. J. (2018). Anthropocentrism: More than just a misunderstood problem. Journal of Agricultural and Environmental Ethics 31, 109-127. https://doi.org/10.1007/s10806-018-9711-1

Kosek, J. (2006). Understories: The political life of forests in northern New Mexico. Duke University Press. https://doi. org/10.1215/9780822388302

Lambeck, K., Yokoyama, Y., Johnston, P., \& Purcell, A. (2000). Global ice volumes at the last glacial maximum and early late glacial. Earth and Planetary Science Letters, 181(4), 513-527. https://doi.org/10.1016/S0012-821X(00)00223-5

Land, N., \& Danis, I. (2016). Movement/ing provocations in early childhood education. Journal of Childhood Studies, 41(3), 26-37. https://doi.org/10.18357/jcs.v41i3.16304

Langford, R. (Ed.). (2019). Theorizing feminist ethics of care in early childhood practice: Possibilities and dangers. Bloomsbury Academic.

Larrabee, M. J. (Ed.). (1993). An ethic of care: Feminist and interdisciplinary perspectives. Routledge.

Lather, P., \& St. Pierre, E. A. (2013). Post-qualitative research. International Journal of Qualitative Studies in Education, 26(6), 629-633. https://doi.org/10.1080/09518398.2013.788752

Louv, R. (2008). Last child in the woods: Saving our children form nature-deficit disorder. Algonquin Books. 
MacLure, M. (2010). The offence of theory. Journal of Education Policy, 25(2), 277-286. https://doi.org/10.1080/02680930903462316

MacLure, M. (2013). Researching without representation? Language and materiality in post-qualitative methodology. International Journal of Qualitative Studies in Education, 26(6), 658-667. https://doi.org/10.1080/09518398.2013.788755

Malone, K. (2016). Reconsidering children's encounters with nature and place using posthumanism. Australian Journal of Environmental Education, 32(1), 42-56. https://doi.org/10.1017/aee.2015.48

Manning, E. (2013). Always more than one: The individuation's dance. Duke University Press. https://doi.org/10.1215/9780822395829

Manning, E. (2014). Wondering the world directly-or, how movement outruns the subject. Body \& Society, 20(3-4), 162-188. https:// doi.org/10.11771357034X14546357

Manning, E. (2016). The minor gesture. Duke University Press. https://doi.org/10.1215/9780822374411

Manning, E., \& Massumi, B. (2014). Thought in the act: Passages in the ecology of experience. University of Minnesota Press.

Massumi, B. (2015). The politics of affect. Polity Press.

McNeil, J. T. (1951). A history of the cure of souls. Harper \& Brothers.

Multispecies Editing Collective. (2017). Troubling species: Care and belonging in a relational world. Rachel Carson Center Perspectives: Transformations in Environment and Society, 1. https://doi.org/10.5282/rcc/7768

Murris, K. (2016). The posthuman child: Educational transformation through philosophy with picturebooks. Routledge Taylor \& Francis Group. https://doi.org/10.4324/9781315718002

Myrstad, A., Sverdrup, T., \& Helgesen, M. B. (2018). Barn skaper sted, sted skaper barn. [Children create place, place creates children]. Fagbokforlaget. https://www.fagbokforlaget.no/Barn-skaper-sted-sted-skaper-barn/19788245022162

Noddings, N. (2003). Caring: A feminine approach to ethics and moral education (2 $2^{\text {nd }}$ ed.). University of California Press.

Noddings, N. (2005). The challenge to care in schools: An alternative approach to education (2 ${ }^{\text {nd }}$ ed.). Teachers College Press.

Oliver, M. (2005). The problem with affordance. E-Learning and Digital Media, 2(4), 402-413. https://doi.org/10.2304elea.2005.2.4.402

Olsson, L. M., Dahlberg, G., \& Theorell, E. (2016). Discplacing identity: Placing aesthetics: early childhood literacy in a globalized world. Discourse: Studies in the Cultural Politics of Education, 37(5), 717-738. https://doi.org/10.1080/01596306.2015.1075711

Pacini-Ketchabaw, V. (2013). Frictions in forest pedagogies: Common worlds in settler colonial spaces. Global Studies of Childhood, 3(4), 355-365. https://doi.org/10.2304gsch.2013.3.4.355

Pacini-Ketchabaw, V., Taylor, A., \& Blaise, M. (2016). Decentring the human in multispecies ethnographies. In C. A. Taylor \& C. Hughes (Eds.), Posthuman research practices in education (pp. 149-167). Palgrave Macmillan.

Prensky, M. (2001). Digital natives, digital immigrants part 1. On the Horizon 9(5), 1-6. https://doi.org/10.1108/10748120110424816

Preston, K. M. (2019). Artist statement. https://karenmareepreston.com/

Prout, A. (2000). The body, childhood, and society. Palgrave Macmillan. https://doi.org/10.1007/978-0-333-98363-8

Puig de la Bellacasa, M. P. (2017). Matters of care: Speculative ethics in more than human worlds. University of Minnesota Press.

Pulcini, E. (2013). Care of the world: Fear, responsibility and justice in the global age (K. Whittle, Trans.). Springer. https://doi. org/10.1007/978-94-007-4482-0

Rae, G. (2014). Deleuze on being as becoming: Multiplicity, difference, and virtuality. In G. Rae (Ed.), Ontology in Heidegger and Deleuze (pp. 116-144). Palgrave Macmillan. https://doi.org/10.1057/9781137404565 6

Rautio, P. (2013). Being nature-interspecies articulation as a species-specific practice of relating to environment. Environmental 
Education Research, 19(4), 445-457. https://doi.org/10.1080/13504622.2012.700698

Rautio, P. (2014). Mingling and imitating in producing spaces for knowing and being: Insights from a Finnish study of child-matter intraaction. Childhood, 21(4), 461-474. https://doi.org/10.11770907568213496653

Rautio, P. (2020). Post-qualitative inquiry: Four balancing acts in crafting alternative stories to live by. Qualitative Inquiry. https://doi. org $/ 10.1177 / 1077800420933297$

Rautio, P., Hohti, R., Leinonen, R.-M., \& Tammi, T. (2017). Reconfiguring urban environmental education with "shitgull" and a "shop." Environmental Education Research, 23(10), 1379-1390. https://doi.org/10.1080/13504622.2017.1325446

Ringrose, J., Warfield, K., \& Zarabadi, S. (2019). Feminist posthumanisms, new materialisms, and education. Routledge Taylor \& Francis Group.

Scarfe, A. (Ed.). (2018). Nature alive: Essays on the emergence and evolution of living agents. Cambridge Scholars.

Snaza, N., \& Weaver, J. (2015). Posthumanism and educational research. Routledge.

St. Pierre, E. A. (2011). Post-qualitative research: The critique and the coming after. In N. K. Denzin \& Y. S. Lincoln (Eds.), The SAGE handbook of qualitative research (4th ed.). SAGE.

St. Pierre, E. A. (2019). Post qualitative inquiry, the refusal of method, and the risk of the new. Qualitative Inquiry. https://doi. org/10.1177/1077800419863005

Tammi, T. (2019). What if schools were lively more-than-human agencements all along? Troubling environmental education with moldschools. Environmental Education Research, 1-16. https://doi.org/10.1080/13504622.2019.1584881

Tammi, T., Rautio, P., Leinonen, R.-M., \& Hohti, R. (2018). Unearthing withling(s): Children, tweezers, and worms and the emergence of joy and suffering in a kindergarten yard. In A. Cutter-Mackenzie et al. (Eds.), Springer international handbook on childhoodnature (pp. 1-13). Springer. https://doi.org/10.1007/978-3-319-51949-4_68-1

Taylor, A. (2017). Beyond stewardship: common world pedagogies for the Anthropocene, Environmental Education Research, 23(10), 1448-1461. https://doi.org/10.1080/13504622.2017.1325452

Taylor, C. A., \& Hughes, C. (2016). Posthuman research practices in education. Palgrave Macmillan. https://doi.org/10.1057/9781137453082

Thiel, J. J. (2018). "A cool place where we make stuff": Co-curating relational spaces of muchness. In C. Schulte \& C. Thompson (Eds.), Communities of practice: Art, play, and aesthetics in early childhood. Landscapes: The arts, aesthetics, and education (vol. 21). Springer. https://doi.org/10.1007/978-3-319-70644-3 3

Tronto, J. C. (1993). Moral boundaries: A political argument for an ethic of care. Routledge.

Ulmer, J., Nordstrom, S., \& Tesar, M. (2017). Writing e/scapes. Reconceptualizing Educational Research Methodology, 8(3), 66-78. https:// doi.org/10.7577/rerm.2551

van Dooren, T. (2020, March 22). Pangolins and pandemics: The real source of this crisis is human, not animal. https://newmatilda. com/2020/03/22/pangolins-and-pandemics-the-real-source-of-this-crisis-is-human-not-animal/

Whitehead, A. N. (1964). Concept of nature Cambridge University Press.

Whitehead, A. N. (1968). Modes of thought. Free Press.

Whitehead, A. N. (1978). Process and reality. Free Press.

Whitehouse, P. (2014, February 17). Postglacial rebound. http://www.antarcticglaciers.org/glaciers-and-climate/sea-level-rise-2/ recovering-from-an-ice-age/\#references 